\title{
Computer Competency: A 7-Year Study to Identify Gaps in Student Computer Skills
}

\author{
George F. Shuster (Corresponding Author) \\ University of New Mexico, College of Nursing, 1 University of New Mexico \\ MSC09 5350, Albuquerque, NM 87131-0001, USA \\ Tel: 1-505-272-5612Ｅ-mail: Gshuster@salud.unm.edu \\ Mona Pearl \\ Assistant Dean of Academic Outreach \\ George Mason University College of Health and Human Services \\ 4400 University Drive, MS 2G7, Fairfax, VA 22030, USA \\ Tel: 1-703-993-1910 E-mail: monapearl@me.com
}

Received: March 8, 2011 Accepted: April 11, $2011 \quad$ Published: November 1, 2011

doi:10.5539/ies.v4n4p137

URL: http://dx.doi.org/10.5539/ies.v4n4p137

\begin{abstract}
Computer competency is crucial to student success in higher education. Assessment of student knowledge related to specific computer competencies can provide faculty with important information about the strengths and weaknesses of their students' computer competency skills. The purpose of this study was to identify the competency level of two groups of nursing students (registered nurses [RNs; $n=236$ ] and traditional nursing students $[n=407]$ ) over a 7 -year period to assess which computer competencies need the most support and to determine how computer competencies varied with successive groups of students. Results indicated that the competency of students increased with each successive group of students. Results also showed that there were significant differences in computer competency levels between the RN and traditional student groups. Competency varied across technological functions, with students having the lowest competency levels in the Data Inquiry competency dimension.
\end{abstract}

Keywords: Computer skills, Online learning, Student assessment

\section{Background}

Due to the vast amount of knowledge available via technology, higher education is inextricably linked with computer usage and access. Consequently, education can only be as good as the computer competency skills of both the teacher and the learner. This study explored the computer competency of undergraduate students enrolled at a college of nursing in the southwestern United States and compared two different groups of nursing students who were completing a Bachelor of Science in Nursing (BSN) degree. One group consisted of traditional students in their junior year of a 4-year undergraduate baccalaureate program who had not worked as registered nurses (RNs). The second group was composed of RNs who entered nursing practice through an associate's degree program, had experience in nursing, and had returned to college to complete a BSN degree (RN to BSN program). A significant number of courses in the RN to BSN program were either offered completely online or were Web-enhanced via the learning platform of WebCT. Both programs used distance education to deliver the curriculum. Computer competency varies greatly between these groups related to student age, the amount of time since enrollment in a college program, societal advances, geographical location in a largely rural state, and general life experiences.

\section{Significance}

Distance education is prevalent in U.S. higher education today; more than 3.9 million students and $20 \%$ of all higher education students were enrolled in at least one online course in Fall 2007 (Allen \& Seaman, 2008). Globally, scholars have commented on nursing student experiences and satisfaction with online technology (Atack, 2003; Barakzai \& Fraser, 2005; Hyde \& Murray, 2005; Lin, Lin, Jiang, \& Lee, 2007; Mancuso-Murphy, 2007), evaluation of specific courses (Huckstadt \& Hayes, 2005; Olson, Stedman-Smith, \& Fredrickson, 2005; Ryan \& Mulholland, 2006; Vandenhouten \& Block, 2005), specific learning strategies (Locatis et al., 2006; McLeod \& Barbara, 2005), 
role of faculty (Ryan, Carlton, \& Ali, 2004; Ryan, Hodson-Carlton, \& Ali, 2005), and student learning patterns online (Thiele, 2003). McNeil et al. (2003) surveyed 266 nursing programs in the United States to identify perceptions of information technology knowledge, skills, and competencies among students, faculty, and practicing nurses. They found that only $50 \%$ of the undergraduate programs required students to enter with novice word processing and email skills; however, on graduation, $80 \%$ of the programs expected students to demonstrate computer competency skills. Collectively, all of these studies illustrate how rapidly computer technology has proliferated and how integral it is to higher education. However, there is little research actually pointing to specific student computer competencies and skills.

\section{Literature Review}

Kenny (2002) conducted a qualitative study of 21 Australian students and found a major theme of "computer confidence." Students identified this as both enhancing and detracting from student learning because most had little experience with computers prior to nursing school. A leading cause of frustration and anxiety in their program was related to computer hardware and software, specifically identifying email, presentation software, spreadsheets, databases, and literature searches as most relevant. Interestingly, there was also a minority of students with extensive backgrounds in computers who were frustrated by peers who lacked computer experience. This study illustrates the diversity among students, as well as the need for schools to provide the means to help students who need to improve their computer competency level to maximize their learning and to use computer technology as a means for both on-the-ground and distance students to successfully form a learning community.

Ornes \& Gassert (2007) examined faculty syllabi to determine the informatics content present in 18 nursing courses. They found that students were not routinely exposed to computerized learning, faculty were a significant barrier to students learning increased computer skills, and students were not adequately prepared to use information technology. The competencies assessed were broad applications of administration, communication, data access, documentation, patient monitoring, desktop software, and systems, with a primary focus on patient clinical information systems. Although this provides an overview of informatics capabilities, it does not delineate specific computer skills needed and used by both faculty and students. It does indicate a need for faculty to become more skilled themselves to facilitate the development of informatics and computer skills for their students.

McDowell \& Ma (2007) specifically explored computer competency in baccalaureate nursing students at one university in the U.S. mid-Atlantic region from 1997 to 2005 by surveying 411 students on admission and 429 students on graduation. They also explored global categories of microcomputer use, keyboard skills, word processing, spreadsheet experience, database use, email, World Wide Web, bibliographic database search, computerized statistical programs, and presentation packages, but did not report on specific items within these categories. They found that baccalaureate nursing students were not adequately prepared to effectively use technology and according to student self-reports, competencies did not increase during their course work in spreadsheet experience, database search, or the use of statistical programs. These are broad categories requiring many computer skills; however, the specific computer knowledge and competencies needed for both faculty and students were not identified in this study.

Jiang, Chen, \& Chen (2004) examined seven overall domains as well as 100 specific computer competencies for nursing students by surveying 29 experts from nursing-related institutions in Taiwan to ascertain which specific competencies should be developed. In the seven domains, they found that attitudes toward the computer and principles of computer applications were most important, whereas program design and the concepts of hardware, software, and network were least important. In the competency domain of skills in computer usage (which ranked fifth in importance out of the seven domains), the most important skill identified was the ability to use the word processor. Other skills of statistical significance related to education included spreadsheet programs, presentation editing software, management of files, use of peripherals, and use of clinical information systems. Because these experts were identifying skills for the nursing profession overall, specific competencies for students to be successful in a nursing program were not identified.

\section{Research Hypotheses}

The current research study of computer competency examines specific skills and competencies to identify the knowledge needed for effectively leveraging information technology. The research question for this study is: What is the level of computer competency among RN and traditional nursing students for students admitted 1999 to 2005 . Specific hypotheses were:

H1: The level of overall computer competency will be higher among traditional nursing students than among RN students. 
H2: The level of specific skills in the four computer competency categories (General Computer Knowledge, Documents and Documentation, Data Inquiry, and Communications and Surfing) will be higher among traditional nursing students than among RN students.

H3: The lowest competency scores for all students will be in the Data Inquiry category.

H4: The computer competency level among both RN and traditional nursing students will improve each semester after the initial group was admitted in 1999.

H5: Those students who own computers will be more computer literate than those do not.

\section{Methods}

\subsection{Sample}

We evaluated computer competency in a convenience sample of students $(N=643)$ consisting of $236 \mathrm{RNs}$ (average age, 40 years) and 407 traditional nursing students (average age, 28 years). Undergraduate enrollment data indicated that $42 \%$ of the students were minorities (29\% Hispanic, 10\% American Indian, and 3\% Asian/Black). Women made up $94 \%$ of the total sample. Over a period of 7 years, from 1999 to 2005, students in both groups completed a computer competency survey at the start of their nursing program.

The sample was further subdivided into three groups, depending on the year of admission to the program (Table 1). These three groups were labeled as the 2001, 2003, and 2005 groups. The 2001 group $(n=164)$ was admitted in 1999 and 2001; the 2003 group $(n=166)$ was admitted in 2002 and 2003, and the 2005 group $(n=312)$ was admitted in 2004 and 2005. Each of these three groups also reflects the progressive integration of Web-enhanced and fully online Web courses into the program curriculum during the 7-year period of the study. The 2001 group entered at the beginning of the process when only a few courses were Web-enhanced and no courses were completely online. More courses were Web-enhanced when the 2003 group entered in 2002 and 2003. When the 2005 group was admitted, all of the RN-BSN courses were fully online, and the faculty had made significant efforts to Web-enhance almost all courses in the on-the-ground traditional program, and traditional students had the option to take some courses completely online.

\subsection{Measures}

The Computer Competency Survey, which was originally developed at the University of Oregon as a student self-assessment questionnaire, was used in this study. It was modified and used with permission to determine whether students needed additional training or practice to meet the computer-related requirements of the nursing degree program. The Computer Competency Survey consists of 40 Likert-type questions measuring four specific competency dimensions of computer competency (10 questions in each subscale): General Computer Knowledge (software and hardware), Documents and Documentation (word processing), Data Inquiry (databases and search engines), and Communications and Surfing (e-mail, computer conferencing, and the Web). The four competency dimensions are scored separately, and higher scores indicate a higher level of computer competency. Cronbach's alpha results for the subscales measuring the four competency dimensions were between .89 and .64.

Completion of the survey was accomplished in 10 to 15 minutes. Potential scores range from 0 to 80 for the overall survey and from 0 to 20 for each of the four subscales. To determine their level of competency, students answered each question using a 3-point Likert scale: 2 points for yes, 1 point for not sure, but likely, and 0 points for no or unlikely. Students were also told that if they scored 16 points or more for any of the four specific competency dimensions of computer competency, they probably had the skill level needed in that specific competency dimension for this BSN program; but if they scored between 10 and 15, although they had a significant amount of familiarity, they were given the suggestion that it would be beneficial to develop additional computer competency skills in that specific competency dimension. If students scored below 10, they were advised to obtain additional training or practice to be successful in applying those skills in the online education environment.

\subsection{Procedure}

Following approval from the university's Institutional Review Board, a cross-sectional survey was used to collect data over a period of 7 years. The Computer Competency Survey was given at the beginning of an identified required course placed in the initial part of the nursing curriculum for both $\mathrm{RN}$ and traditional undergraduate students.

\subsection{Data Analysis}

SPSS (v. 17.0) was used for data analyses. Descriptive analyses (frequencies, means, medians, and standard deviations) were calculated for all demographic and study variables. These descriptive analyses were done for each of the three periods for the RN group and traditional group separately and again for the two groups combined. As a 
preliminary step, data were first analyzed for normality, skew, and kurtosis, as well as assumptions for parametric and nonparametric statistical analysis. The dependent variables (total computer competency and the four competency dimensions) for the individual RN and traditional groups had a slight negative skew but met the assumptions for parametric statistical analysis using $t$ tests. However, the three combined RN-traditional groups (2001, 2003, and 2005) did not. Although the distributions of the dependent variable data were similar, the results indicated a negative skew for the both the Total Computer Competency Scale and some of the subscales. Results from Kolmogorov-Smirnov tests for deviation from normality were small but significant (Pett, 1997). Consequently, the fourth hypothesis was tested by nonparametric statistics using the Kruskal-Wallis test and, when appropriate, with post-hoc analysis using Mann-Whitney U tests. Assumptions for using both the Kruskal-Wallis test and Mann-Whitney U tests were met (Pett, 1997). The last hypothesis was tested using a $t$ test for unequal groups. Each hypothesis was tested in turn.

\section{Results}

The results for all four competency dimensions and total computer competency indicated that the total computer competency score was higher for traditional students than for RN students, and the level of computer skills in all four competency dimensions was also consistently higher for traditional students than for RN students (Table 2). The effect size for the differences between the RN and traditional students was small for the General Computer Knowledge, Data Inquiry, and Communications and Surfing competency dimensions, whereas the effect size for the Documents and Documentation competency dimension and the Total Computer Competency Scale were moderate. The mean average for each competency dimension is reported in Table 2. These mean averages were lowest for the Data Inquiry competency dimension.

Computer competency levels were also compared among the three groups as a whole using nonparametric Kruskal-Wallis tests and, where appropriate, post-hoc Mann-Whitney U tests. The data analysis indicated differences among the three groups for total computer competency and three of the four competency dimensions. Results of the statistical analysis for the Total Computer Competency Scale were significant $\left(\mathrm{X}^{2} \mathrm{~K}-\mathrm{W}(2, \mathrm{~N}=634)=17.35\right.$, $p<.000)$. There were also significant results for the Kruskal-Wallis tests of the Data Inquiry $\left(\mathrm{X}_{\mathrm{K}-\mathrm{W}(2, \mathrm{~N}=636)}^{2}=14.05\right.$, $p<.001)$, General Computer Knowledge $\left(\mathrm{X}_{\mathrm{K}-\mathrm{W}(2, \mathrm{~N}=638)}^{2}=13.95, p<.001\right)$, and Communications and Surfing competency dimensions $\left(\mathrm{X}_{\mathrm{K}-\mathrm{W}(2, \mathrm{~N}=630)}^{2}=17.76, p<.000\right)$. There were no differences among any of the three groups for the Documents and Documentation competency dimension. Where differences among the three groups were significant, they were consistently between the 2001 and 2003 groups and between the 2001 and 2005 groups, but not between the 2003 and 2005 groups (Tables 3 and 4).

Although only $6.8 \%$ of students ( 47 of 625 ) who answered the question about owning a computer did not own one, we compared that subgroup with the rest of the students using a $t$ test because of potential implications for program planning. Students who did not own a computer had significantly lower scores on the Total Computer Competency Scale, as well as in all of the competency dimensions than those who did own one $(t=4.63, p<.000$; see Table 5).

Finally, examination of the individual question averages for both the traditional and RN student groups indicated that there were seven questions representing skills in which the RN students' mean score was higher than the traditional students' mean score. A Mann-Whitney U test was conducted to evaluate whether the differences were significant. Only two of these skills were significantly higher for RN students than for traditional students. These were: "Have you ever used an electronic clinical information system?" $(z=-2.74, p \leq .006)$ and "Have you ever participated in asynchronous computer conferencing?" $(z=-2.38, p \leq .017$; see Tables 6-9).

\section{Discussion}

The overall research question asked: What is the level of computer competency among RN and traditional nursing students? Computer competency of the traditional students was higher than the RNs for each competency dimension and overall. However, for seven specific items, RNs scored slightly higher than the traditional students. These were related to competencies of knowledge of random access memory (RAM), knowledge of pathways, finding the Command line on a programming screen, electronic clinical information systems, medical subject headings (MeSH), asynchronous computer conferencing, and SHOUTING in an email. It is possible that these types of skills are more prevalent for students who are already working in a clinical environment. Because the nursing program only accepts traditional students in their junior year, these students have already taken 2 years of undergraduate baccalaureate education prerequisites at the university before entering the upper-division nursing program; therefore, they may have a greater familiarity with computer and information management related to academic study. However, we were surprised that this knowledge was not more extensive.

\subsection{Hypothesis Testing}

Five specific hypotheses were tested in this study. The results supported the first two hypotheses: the level of overall computer competency among traditional students was higher than the computer competency level among RN 
students (H1), and traditional students consistently demonstrated higher levels of computer competency in the four computer competency dimensions than RN students (H2). Effect size is one measure of the strength of the relationship between membership in either the traditional or the RN student group and computer competency. The effect size of the differences for the Total Computer Competency Scale and for the Documents and Documentation competency dimension was moderate. This may suggest the need for additional support for RN students involving computer competency overall and documentation in particular because these are the areas of greatest difference between RN students and traditional students.

The mean average for the Data Inquiry competency dimension supported our third hypothesis, that all students will have the lowest competency scores in the Data Inquiry category. This was the category with the lowest average score and the most need for improvement in all groups, suggesting that further attention needs to be paid to skills in this specific competency. This finding has important implications because undergraduate students are expected to be able to access informational resources online. Because of the overwhelming amount of knowledge available today, this has become a critical skill. Finding relevant and timely information is difficult when there are so many sources and so much knowledge is being funneled into databases. The nature of almost any discipline today involves the continual updating of practice based on current evidence; therefore, there is a greater need to master this skill. Additionally, students enrolled in distance education programs must rely on their ability to sample the literature and access information. The ability to obtain peer-reviewed journals and other online data, such as epidemiologic information and clinical practice guidelines, is a critical skill for students in nursing and other disciplines.

The findings also supported the fourth hypothesis. The computer competency level among both new RN and new traditional students improved each semester after the initial, or 2001, group, with average scores increasing for the 2003 and 2005 groups. The differences between individual groups were significant between the 2001 and 2003 groups and between the 2001 and 2005 groups. However, there were no statistically significant differences between the 2003 and 2005 groups. This was true when the RN and traditional cohorts were combined and when they were calculated separately. As the groups progressed in terms of admission dates, it appears that students were entering the program with a greater degree of computer knowledge. This finding has implications for program planning because student computer competency needs appear to be continuing to change over time, although this larger trend may obscure differences between younger students and older students who are returning for their undergraduate degree.

Hypothesis 5 was also supported by the results. Those students who owned computers were more computer literate in every competency dimension subscale and in overall computer competency than were those who did not. Although the effect size was small for these students, the results suggest that it is important to survey all students to see if they own a computer, and for the students who do not own their own computers, to have additional resources available and perhaps remedial computer support. In this study, only $7 \%$ of the students did not own a computer, a fairly small percentage of the overall group. However, it is important for educators to recognize that it is often a small percentage of students within a given class who require the majority of additional faculty effort. If that need for additional, individual faculty assistance is associated with specific computer competencies, it is best addressed at the program level and not at the individual faculty or course level.

\subsection{Study Limitations}

Study limitations include not incorporating a competency dimension related to clinical information systems, although it was reasonable to assume that traditional students had very little, if any, exposure to clinical information systems. Also, the average age of the RN group was much higher than the average age of the traditional-student group. This age difference may account for some percentage of the results, although the average older age for RN students might also be offset by familiarity with the use of electronic records and ordering systems in their own clinical practice.

\section{Conclusions}

Advances in computer technology, Web-based educational software, and the speed of data transfer across the World Wide Web make student computer competency an integral part of both onsite and distance education for students today. Study results from this survey over a 7-year period indicate that student levels of computer competency initially improved but then started to plateau. Results also indicate that there are significant differences in overall computer competency and in specific computer competency dimensions, among different types of students (i.e., RN and traditional). The competency skills identified as needing the most improvement are in the Data Inquiry category.

Many students do not know what computer competencies are needed to be successful in Web-based courses or whether they have the level of skills required. Screening incoming students for specific computer competencies enables educational programs to identify not only individual students in need of additional support but also specific 
competencies that might be lacking among the students as a group. Data Inquiry is an example of a computer dimension requiring additional support for most of the students who participated in this survey. Remedial actions can then be taken for students depending on the nature of the problem and the number of students involved. These actions might include requiring students to take a computer competency course to develop their skills before taking courses in the program. This is particularly important in distance education. If the problem is more widespread among the entire group, tailored tutorials could be developed and even streamed across the World Wide Web using a format such as Flash.

Many faculty members are reluctant to teach online or to use Web enhancement for their courses because they view themselves as content experts and not experts in computer technology. They do not want to find themselves solving student computer competency problems. Computer competency surveys that can identify what competencies incoming students do or do not possess (i.e., specific computer competency skills) enable educational programs to focus on addressing such problems at the system level rather than at the individual student level within specific courses.

Student computer competency then becomes an enabler for successful learning rather than a barrier. Identification of specific competencies allows both the learner and the educator to engage in the learning process with a common technical language and skill set. The creative process, development of critical thinking skills, and intellectual curiosity can all be aided by the use of technology, which is a synergistic element of the learning process. A minimum skill set is required for a level playing field to exist between students and faculty and for common exploration of educational concepts and theories.

\section{References}

Allen, I. E., \& Seaman, J. (2008). Staying the course: Online education in the United States, [Online] Available: http://www.sloan-c.org/publications/survey/pdf/staying_the_course.pdf (January 5, 2009)

Atack, L. (2003). Becoming a web-based learner: Registered nurses' experiences. Journal of Advanced Nursing, 44(3), 289-297. http://dx.doi.org/10.1046/j.1365-2648.2003.02804.x

Barakzai, M. D., \& Fraser, D. (2005). The effect of demographic variables on achievement in and satisfaction with online coursework. Journal of Nursing Education, 44(8), 373-380

Huckstadt, A., \& Hayes, K. (2005). Evaluation of interactive online courses for advanced practice nurses. Journal of American Academy of Nurse Practitioners, 17(3), 85-89. http://dx.doi.org/10.1111/j.1041-2972.2005.0015.x

Hyde, A., \& Murray, M. (2005). Nurses' experiences of distance education programmes. Journal of Advanced Nursing, 49(1), 87-95. http://dx.doi.org/10.1111/j.1365-2648.2004.03267.x

Jiang, W. W., Chen, W., \& Chen, Y. C. (2004). Important computer competencies for the nursing profession. Journal of Nursing Research, 12(3), 213-225. http://dx.doi.org/10.1097/01.JNR.0000387505.98877.6d

Kenny, A. (2002). Online learning: Enhancing nurse education? Journal of Advanced Nursing, 38(2), 127-135. http://dx.doi.org/10.1046/j.1365-2648.2002.02156.x

Lin, J. S., Lin, K. C., Jiang, W. W., \& Lee, T. T. (2007). An exploration of nursing informatics competency and satisfaction related to network education. Journal of Nursing Research, 15(1), 54-66. http://dx.doi.org/10.1097/01.JNR.0000387599.17285.76

Locatis, C., Gaines, C., Liu, W. L., Gill, M., Carney, J., Foster, J., et al. (2006). Journal of Medical Library Association, 94(4), 464-468

Mancuso-Murphy, J. (2007). Distance education in nursing: An integrated review of online nursing students' experiences with technology-delivered instruction. Journal of Nursing Education, 46(6), 252-260

McDowell, D. E., \& Ma, X. (2007). Computer literacy in baccalaureate nursing students during the last 8 years. CIN: Computers, Informatics, Nursing, 25(1), 30-36

McLeod, S., \& Barbara, A. (2005). Online technology in rural health: Supporting students to overcome the tyranny of distance. Australian Journal of Rural Health, 13, 276-281. http://dx.doi.org/10.1111/j.1440-1584.2005.00717.x

McNeil, B. J., Elfrink, V. L., Bickford, C. J., Pierce, S. T., Beyea, S. C., Averill, C., et al. (2003). Nursing information technology knowledge, skills, and preparation of student nurses, nursing faculty, and clinicians: A U.S. survey. Journal of Nursing Education, 42(8), 341-349

Olson, D., Stedman-Smith, M., \& Fredrickson, A. (2005). Environmental health and nursing: Piloting a technology-enhanced distance learning module. AAOHN Journal, 53(8), 353-359 
Ornes, L. L., \& Gassert, C. (2007). Computer competencies in a BSN program. Journal of Nursing Education, 46(2), $75-78$

Pett, M. A. (1997). Nonparametric statistics for health care research. Thousand Oaks, CA: Sage Publications.

Ryan, M., Carlton, K. H., \& Ali, N. S. (2004). Role of faculty in distance learning and changing pedagogies. Nursing Education Perspectives, 25(2), 73-80

Ryan, M., Hodson-Carlton, K., \& Ali, N. S. (2005). A model for faculty teaching online: Confirmation of a competency dimensional matrix. Journal of Nursing Education, 44(8), 357-365

Ryan, M. T., \& Mulholland, C. W. (2006, January). Evaluation of a distance-learning immunology and pathology module in a postgraduate biomedical science course. Continuing Education Topics \& Issues, 62(1), 42-47

Thiele, J. E. (2003). Learning patterns of online students. Journal of Nursing Education, 42(8), 364-366

Vandenhouten, C., \& Block, D. (2005). A case study of a distance-based public health nursing/community health nursing-practicum. Public Health Nursing, 22(2), 166-171. http://dx.doi.org/10.1111/j.0737-1209.2005.220210.x

Table 1. Number and percentage of RN and traditional nursing students by group

\begin{tabular}{|c|c|c|}
\hline Group & $\begin{array}{c}\text { RN } \\
n(\%)\end{array}$ & $\begin{array}{c}\text { Traditional } \\
n(\%)\end{array}$ \\
\hline $\begin{array}{l}2001 \text { Group } \\
(1999-2001)\end{array}$ & $51(21.7)$ & $113(27.9)$ \\
\hline $\begin{array}{l}2003 \text { Group } \\
(2002-2003)\end{array}$ & $70(29.8)$ & $96(23.2)$ \\
\hline $\begin{array}{l}2005 \text { Group } \\
(2004-2005)\end{array}$ & $114(48.5)$ & $198(48.9)$ \\
\hline Total & 235 & 407 \\
\hline
\end{tabular}

Table 2. $T$-test results for RN $(n=236)$ and traditional $(n=407)$ students among the four competency dimensions and Total Computer Competency

\begin{tabular}{|c|c|c|c|c|}
\hline $\begin{array}{l}\text { Competency } \\
\text { dimension }\end{array}$ & $\begin{array}{c}\text { RN } \\
\text { Mean (SD) }\end{array}$ & $\begin{array}{l}\text { Traditional } \\
\text { Mean (SD) }\end{array}$ & $t$ test $^{*}$ & $p$ value \\
\hline \multirow{2}{*}{$\begin{array}{l}\text { General Computer } \\
\text { Knowledge }\end{array}$} & $15.62(3.70)$ & $16.18(2.80)$ & -2.29 & .011 \\
\hline & $n=235$ & $n=405$ & & \\
\hline \multirow{2}{*}{$\begin{array}{l}\text { Documents and } \\
\text { Documentation }\end{array}$} & $14.77(4.40)$ & $17.33(2.37)$ & -8.1 & .000 \\
\hline & $n=235$ & $n=407$ & & \\
\hline \multirow{2}{*}{$\begin{array}{l}\text { Data Inquiry (Databases } \\
\text { and Search Engines) }\end{array}$} & $11.85(4.07)$ & $13.20(3.38)$ & -4.0 & .000 \\
\hline & $n=234$ & $n=404$ & & \\
\hline \multirow{2}{*}{$\begin{array}{l}\text { Communications and } \\
\text { Surfing }\end{array}$} & $14.32(3.58)$ & $15.89(2.64)$ & -5.26 & .000 \\
\hline & $n=230$ & $n=402$ & & \\
\hline \multirow{2}{*}{$\begin{array}{l}\text { Total Computer } \\
\text { Competency Scale }\end{array}$} & $56.55(13.15)$ & $62.61(8.83)$ & -6.03 & .000 \\
\hline & $n=235$ & $n=407$ & & \\
\hline
\end{tabular}


Table 3. Comparison of combined $\mathrm{RN}$ and traditional student year-groups $(N=643)$ for Total Computer Competency and the four subscales

\begin{tabular}{lccc}
\hline Group & Comparison & $\begin{array}{c}\text { Mann-Whitney } \boldsymbol{z} \\
\text { statistic }\end{array}$ & Test of significance $^{*}$ \\
\hline 1 vs. 2 & 2001 vs. 2003 & -3.65 & .000 \\
\hline 1 vs. 3 & 2001 vs. 2005 & -3.75 & .000 \\
\hline 2 vs. 3 & 2003 vs. 2005 & .33 & $\mathrm{~ns}$ \\
\hline
\end{tabular}

${ }^{*}$ A $p$ value of .05 or less was accepted as statistical significance.

Table 4. Comparison of combined RN and traditional student year-groups $(N=643)$ and the four competency dimension subscales

\begin{tabular}{lcc}
\hline Comparison & $\begin{array}{c}\text { Mann-Whitney } \boldsymbol{z} \\
\text { statistic }\end{array}$ & $\begin{array}{c}\text { Level of } \\
\text { significance* }\end{array}$ \\
\hline 2001 vs. 2003 & -3.45 & .001 \\
\hline 2001 vs. 2005 & -2.98 & .003 \\
\hline 2003 vs. 2005 & -1.36 & ns \\
\hline 2001 vs. 2003 & -3.62 & .000 \\
\hline 2001 vs. 2005 & -2.98 & .003 \\
\hline 2003 vs. 2005 & -2.68 & .007 \\
\hline 2001 vs. 2003 & -3.1 & .002 \\
\hline 2001 vs. 2005 & -4.1 & .000 \\
\hline 2003 vs. 2005 & .248 & ns \\
\hline A $p$ value of .05 or less was accepted as statistical significance.
\end{tabular}

Table 5. Overall computer competency and four subscale comparisons between students who owned computers $(n=$ 576) and students who did not own computers $(n=47)$

\begin{tabular}{lcc}
\hline $\begin{array}{l}\text { Total Scale and competency dimension } \\
\text { subscales }\end{array}$ & $\boldsymbol{t}$ test & $\begin{array}{c}\text { Level of } \\
\text { significance }\end{array}$ \\
\hline Total Computer Competency Scale & 4.63 & .000 \\
\hline General Computer Knowledge & 4.07 & .000 \\
\hline Communications and Surfing & 5.52 & .000 \\
\hline Documents and Documentation & 1.97 & .027 \\
\hline Data Inquiry & 2.79 & .005 \\
\hline
\end{tabular}

${ }^{*}$ A $p$ value of .05 or less was accepted as statistical significance. 
Table 6. Results for RN and traditional students regarding questions in the General Computer Knowledge subscale

\begin{tabular}{|c|c|c|}
\hline Questions & $\begin{array}{c}\text { RN } \\
\text { Mean (SD) }\end{array}$ & $\begin{array}{l}\text { Traditional } \\
\text { Mean (SD) }\end{array}$ \\
\hline \multirow{2}{*}{$\begin{array}{l}\text { Can you name one input device and one } \\
\text { output device? }\end{array}$} & $1.29(.77)$ & $1.38(.74)$ \\
\hline & $n=235$ & $n=404$ \\
\hline \multirow{2}{*}{$\begin{array}{l}\text { Do you know what RAM stands for and } \\
\text { how much RAM your computer has? }\end{array}$} & $1.25(.78)$ & $1.17(.77)$ \\
\hline & $n=235$ & $n=391$ \\
\hline \multirow{2}{*}{$\begin{array}{l}\text { Do you know what an "icon" is and what } \\
\text { to do with it? }\end{array}$} & $1.94(.25)$ & $1.98(.16)$ \\
\hline & $n=235$ & $n=391$ \\
\hline \multirow{2}{*}{$\begin{array}{l}\text { Do you know how to use a mouse to } \\
\text { "drag" an item? }\end{array}$} & $1.94(.25)$ & $1.98(.15)$ \\
\hline & $n=234$ & $n=400$ \\
\hline \multirow{2}{*}{$\begin{array}{l}\text { Do you know the acceptable form for a } \\
\text { filename? }\end{array}$} & $1.26(.76)$ & $1.46(.69)$ \\
\hline & $n=235$ & $n=396$ \\
\hline \multirow{2}{*}{$\begin{array}{l}\text { Do you know what a pathway is, and can } \\
\text { you find a file with a pathway? }\end{array}$} & $1.17(.77)$ & $1.14(.80)$ \\
\hline & $n=233$ & $n=394$ \\
\hline \multirow{2}{*}{ Do you know what a modem is used for? } & $1.72(.57)$ & $1.84(.42)$ \\
\hline & $n=233$ & $n=404$ \\
\hline \multirow{2}{*}{$\begin{array}{l}\text { Do you know how to reboot your } \\
\text { computer? }\end{array}$} & $1.74(.58)$ & $1.84(.49)$ \\
\hline & $n=232$ & $n=404$ \\
\hline \multirow{2}{*}{$\begin{array}{l}\text { Can you find the command line on a } \\
\text { Windows program screen? }\end{array}$} & $1.54(.68)$ & $1.50(.67)$ \\
\hline & $n=233$ & $n=402$ \\
\hline \multirow{2}{*}{$\begin{array}{l}\text { Do you know how to open up more than } \\
\text { one program at a time in Windows and } \\
\text { move quickly between them? }\end{array}$} & $1.75(.55)$ & $1.90(.36)$ \\
\hline & $n=232$ & $n=402$ \\
\hline \multirow{2}{*}{$\begin{array}{l}\text { Total Scale Score for General Computer } \\
\text { Knowledge }\end{array}$} & $15.62(3.70)$ & $16.18(2.80)$ \\
\hline & $n=235$ & $n=405$ \\
\hline
\end{tabular}

Note: $\mathrm{RN}=$ registered nurse. $\mathrm{RAM}=$ random access memory. 
Table 7. Results for RN and traditional students regarding questions in the Documents and Documentation Subscale

\begin{tabular}{|c|c|c|}
\hline Questions & $\begin{array}{c}\text { RN } \\
\text { Mean (SD) }\end{array}$ & $\begin{array}{l}\text { Traditional } \\
\text { Mean (SD) }\end{array}$ \\
\hline \multirow{2}{*}{$\begin{array}{l}\text { Do you know what font or typeface } \\
\text { is? }\end{array}$} & $1.91(.31)$ & $1.99(.12)$ \\
\hline & $n=236$ & $n=394$ \\
\hline \multirow{2}{*}{$\begin{array}{l}\text { Do you know how to right and left } \\
\text { justify a document? }\end{array}$} & $1.60(.71)$ & $1.93(.31)$ \\
\hline & $n=235$ & $n=394$ \\
\hline \multirow{2}{*}{$\begin{array}{l}\text { Do you know how to cut and paste a } \\
\text { block of text? }\end{array}$} & $1.73(.61)$ & $1.97(.19)$ \\
\hline & $n=236$ & $n=394$ \\
\hline \multirow{2}{*}{$\begin{array}{l}\text { Do you know how to use a mouse to } \\
\text { "drag" a block of text? }\end{array}$} & $1.66(.63)$ & $1.90(.39)$ \\
\hline & $n=236$ & $n=404$ \\
\hline \multirow{2}{*}{$\begin{array}{l}\text { Do you know how to reset margins } \\
\text { in your word processor? }\end{array}$} & $1.53(.71)$ & $1.85(.43)$ \\
\hline & $n=234$ & $n=404$ \\
\hline \multirow{2}{*}{$\begin{array}{l}\text { Do you know the difference } \\
\text { between "Insert" and "Type over"? }\end{array}$} & $1.39(.83)$ & $1.74(.57)$ \\
\hline & $n=236$ & $n=404$ \\
\hline \multirow{2}{*}{$\begin{array}{l}\text { Do you know what the clipboard } \\
\text { does? }\end{array}$} & $1.03(.85)$ & $1.44(.74)$ \\
\hline & $n=236$ & $n=404$ \\
\hline \multirow{2}{*}{$\begin{array}{l}\text { Do you know how to tell your word } \\
\text { processor to paginate? }\end{array}$} & $.77(.84)$ & $.89(.81)$ \\
\hline & $n=236$ & $n=394$ \\
\hline \multirow{2}{*}{ Can you use a spell checker? } & $1.90(.38)$ & $1.99(.10)$ \\
\hline & $n=236$ & $n=394$ \\
\hline \multirow{2}{*}{$\begin{array}{l}\text { Do you know how to create a page } \\
\text { break? }\end{array}$} & $1.25(.88)$ & $1.63(.63)$ \\
\hline & $n=236$ & $n=404$ \\
\hline \multirow{2}{*}{$\begin{array}{l}\text { Total Scale Score for Documents } \\
\text { and Documentation Skills }\end{array}$} & $14.77(4.40)$ & $17.33(2.37)$ \\
\hline & $n=236$ & $n=407$ \\
\hline
\end{tabular}


Table 8. Results for RN and traditional students regarding questions in the Data Inquiry (Databases and Search Engines) Subscale

\begin{tabular}{|c|c|c|}
\hline Questions & $\begin{array}{c}\text { RN } \\
\text { Mean (SD) }\end{array}$ & $\begin{array}{l}\text { Traditional } \\
\text { Mean (SD) }\end{array}$ \\
\hline $\begin{array}{l}\text { In a database, do you know what a } \\
\text { record is? }\end{array}$ & $\begin{array}{l}1.04(.78) \\
n=234\end{array}$ & $\begin{array}{c}1.29(.74) \\
n=404\end{array}$ \\
\hline $\begin{array}{l}\text { Can you explain how the } \\
\text { following fit together: file, } \\
\text { records, and fields? }\end{array}$ & $\begin{array}{l}.81(.73) \\
n=233\end{array}$ & $\begin{array}{l}.96(.76) \\
n=394\end{array}$ \\
\hline $\begin{array}{l}\text { Have you ever searched an } \\
\text { electronic library catalog? }\end{array}$ & $\begin{array}{l}1.53(.78) \\
n=233\end{array}$ & $\begin{array}{l}1.77(.60) \\
n=394\end{array}$ \\
\hline $\begin{array}{l}\text { Have you ever used an electronic } \\
\text { clinical information system? }\end{array}$ & $\begin{array}{l}.99(.88) \\
n=234\end{array}$ & $\begin{array}{l}.80(.89) \\
n=404\end{array}$ \\
\hline $\begin{array}{l}\text { Have you ever used a personal } \\
\text { database, such as a computerized } \\
\text { address list? }\end{array}$ & $\begin{array}{l}1.35(.85) \\
n=234\end{array}$ & $\begin{array}{l}1.50(.81) \\
n=393\end{array}$ \\
\hline $\begin{array}{l}\text { Have you ever searched a } \\
\text { database for a particular item? }\end{array}$ & $\begin{array}{l}1.78(.49) \\
n=234\end{array}$ & $\begin{array}{c}1.86(.44) \\
n=394\end{array}$ \\
\hline $\begin{array}{l}\text { Have you ever sorted a database } \\
\text { to put the records in a particular } \\
\text { order? }\end{array}$ & $\begin{array}{l}.78(.86) \\
n=232\end{array}$ & $\begin{array}{c}1.15(.88) \\
n=404\end{array}$ \\
\hline $\begin{array}{l}\text { Do you know what difference } \\
\text { "AND" or "OR" would make in } \\
\text { combining the results of two } \\
\text { searches? }\end{array}$ & $\begin{array}{c}1.43(.78) \\
n=234\end{array}$ & $\begin{array}{l}1.73(.60) \\
n=398\end{array}$ \\
\hline $\begin{array}{l}\text { Have you ever used a "search } \\
\text { engine" (i.e., Yahoo, Infoseek, } \\
\text { Medline, CINAHL)? }\end{array}$ & $\begin{array}{c}1.95(.27) \\
n=230\end{array}$ & $\begin{array}{c}1.98(.20) \\
n=396\end{array}$ \\
\hline $\begin{array}{l}\text { Do you know what MeSH stands } \\
\text { for and how to use them? }\end{array}$ & $\begin{array}{l}.19(.46) \\
n=232\end{array}$ & $\begin{array}{l}.16(.39) \\
n=398\end{array}$ \\
\hline $\begin{array}{l}\text { Total Scale Score for Data Inquiry } \\
\text { (Databases and Search Engines) } \\
\text { Skills }\end{array}$ & $\begin{array}{c}11.85(4.07) \\
n=234\end{array}$ & $\begin{array}{c}13.20(3.38) \\
n=404\end{array}$ \\
\hline
\end{tabular}


Table 9. Results for RN and traditional students regarding questions in the Communications and Surfing Subscale

\begin{tabular}{|c|c|c|}
\hline Questions & $\begin{array}{c}\text { RN } \\
\text { Mean (SD) }\end{array}$ & $\begin{array}{l}\text { Traditional } \\
\text { Mean (SD) }\end{array}$ \\
\hline Do you have an e-mail address? & $\begin{array}{c}1,95(.29) \\
n=230\end{array}$ & $\begin{array}{c}1.95(.30) \\
n=394\end{array}$ \\
\hline $\begin{array}{l}\text { Do you have an Internet provider } \\
\text { for your home or office computer? }\end{array}$ & $\begin{array}{c}1.82(.55) \\
n=230\end{array}$ & $\begin{array}{c}1.84(.52) \\
n=394\end{array}$ \\
\hline $\begin{array}{l}\text { Have you ever subscribed to a } \\
\text { listserv? }\end{array}$ & $\begin{array}{l}1.13(.95) \\
n=229\end{array}$ & $\begin{array}{c}1.65(.72) \\
n=394\end{array}$ \\
\hline $\begin{array}{l}\text { Have you ever used a browser like } \\
\text { Netscape or Internet Explorer to } \\
\text { visit the World Wide Web? }\end{array}$ & $\begin{array}{l}1.69(.68) \\
n=229\end{array}$ & $\begin{array}{l}1.96(.29) \\
n=394\end{array}$ \\
\hline $\begin{array}{l}\text { Have you ever participated in } \\
\text { asynchronous computer } \\
\text { conferencing? }\end{array}$ & $\begin{array}{l}.71(.91) \\
n=228\end{array}$ & $\begin{array}{l}.51(.81) \\
n=394\end{array}$ \\
\hline Do you use e-mail regularly? & $\begin{array}{l}1.61(.75) \\
n=230\end{array}$ & $\begin{array}{c}1.93(.32) \\
n=394\end{array}$ \\
\hline $\begin{array}{l}\text { Do you know what SHOUTING is } \\
\text { in an e-mail message? }\end{array}$ & $\begin{array}{l}1.13(.92) \\
n=230\end{array}$ & $\begin{array}{l}1.03(.93) \\
n=400\end{array}$ \\
\hline $\begin{array}{l}\text { Can you locate three major search } \\
\text { engines on the Web? }\end{array}$ & $\begin{array}{l}1.70(.63) \\
n=230\end{array}$ & $\begin{array}{l}1.86(.45) \\
n=400\end{array}$ \\
\hline $\begin{array}{l}\text { Do you know what an electronic } \\
\text { "bookmark" is and how to create } \\
\text { one? }\end{array}$ & $\begin{array}{l}1.27(.86) \\
n=230\end{array}$ & $\begin{array}{l}1.59(.73) \\
n=400\end{array}$ \\
\hline $\begin{array}{l}\text { Have you ever participated in an } \\
\text { online chat session? }\end{array}$ & $\begin{array}{l}1.31(.88) \\
n=230\end{array}$ & $\begin{array}{c}1.52(.81) \\
n=400\end{array}$ \\
\hline $\begin{array}{l}\text { Total Scale Score for } \\
\text { Communications and Surfing Skills }\end{array}$ & $\begin{array}{c}14.32(3.58) \\
n=230\end{array}$ & $\begin{array}{c}15.89(2.64) \\
n=402\end{array}$ \\
\hline
\end{tabular}

